\title{
CIRCULATING BASOPHILIC LEUCOCYTE COUNTS IN THE NEWBORN
}

\author{
BY \\ ROSS G. MITCHELL \\ From the Department of Child Health, University of St. Andrews, and Maryfield Hospital, Dundee
}

(RECEIVED FOR PUBLICATION SEPTEMBER 27, 1954)

Recent evidence that histamine is present in basophilic leucocytes (Graham, Wheelwright, Parish, Marks and Lowry, 1952; Code and Mitchell, 1954) as well as in tissue mast cells (Riley and West, 1953) has created fresh interest in these cells. Knowledge of variations in the number of circulating basophils is scanty owing to the inaccuracy of smear techniques, but the introduction of a chamber-counting method (Moore and James, 1953) has made it possible to measure even small changes with considerable accuracy. Using this method, basophils have been counted in the capillary blood of healthy infants during the newborn period.

\section{Method and Procedure}

The method used was essentially that described by Moore and James (1953). The intensity of staining with different samples of toluidine blue was found to vary considerably and even the sample which gave the best results (toluidine blue, B.D.H.) had to be used in a higher concentration than that recommended. Moreover, although the counting fluid was found to be satisfactory for older children, haemolysis of red cells in the newborn was incomplete. After numerous trials, satisfactory haemolysis was obtained by reducing the amount of $95 \%$ ethyl alcohol to half that recommended. The modified Moore and James counting fluid for use in newborn infants was therefore as follows:

$$
\begin{array}{cccc}
\text { Toluidine blue (B.D.H.) } & 0.075 \% & \\
\text { in } 0.85 \% \text { saline } . . & . . & . & 40 \mathrm{ml} . \\
95 \% \text { ethyl alcohol .. } & \ldots & . . & 5.5 \mathrm{ml} . \\
\begin{array}{c}
\text { Saturated solution of } \\
50 \% \text { ethyl alcohol }
\end{array} & . . & . . & 1 \mathrm{ml} .
\end{array}
$$

With this fluid, the granules in the basophils stain bright pink, while those in the eosinophils are greenish-yellow. The colours are improved if the $p \mathrm{H}$ of the fluid is carefully adjusted to $\mathrm{pH} 7 \cdot 75$ (James, 1953). Total leucocytes, eosinophils and basophils were counted in the same chamber as described by Moore and James.
The initial counts were made on venous blood from the umbilical cord immediately on delivery; the cord was clamped within a few minutes without waiting for pulsation to cease. All subsequent counts were made on capillary blood obtained by heel stab. A free flow of blood was obtained from the heel without pressure and the first drop was wiped away before filling the pipette. Capillary blood was used for the counts because repeated venepuncture was considered unjustifiable and because the differences between capillary and venous blood have been shown to be small (Lucas, Dearing, Hoobler, Cox, Jones and Smyth, 1921; Findlay, 1946). Moreover, it was felt that counts on capillary blood might have more practical value since blood is more easily obtained from sick infants by heel stab than by venepuncture.

Counts were made at half an hour, four hours, and 24 hours after birth, and thereafter daily to the fifth day, at 1 week and at 6 weeks. All counts from 24 hours onwards were made between 12 noon and 2 p.m. to avoid the possibility of diurnal variation, although this is not known to occur. The counts were made on 20 healthy infants born spontaneously at full term after normal pregnancies. The babies were unselected except in so far as they were born between 11 a.m. and 3 p.m., so that counts on subsequent days would be as nearly as possible at 24-hour intervals.

\section{Results}

Table I shows the values obtained for serial basophil counts in each infant. The number of circulating basophils rose after birth to reach a maximum at 24 hours in 17 of the 20 infants, and at four hours in the remaining three. There was a rapid fall between one and three days and a more gradual further decline to the lowest level usually reached on the fifth day. At 1 week the mean count had risen slightly and at 6 weeks was double that recorded at 1 week (Table 2). Although the 
TABLE 1

NUMBERS OF BASOPHILS PER C.MM. OF BLOOD

\begin{tabular}{|c|c|c|c|c|c|c|c|c|c|c|}
\hline Infant No. & Birth & Hour & Hours & $\stackrel{24}{\text { Hours }}$ & $\stackrel{2}{\text { Days }}$ & $\begin{array}{c}3 \\
\text { Days }\end{array}$ & $\begin{array}{c}4 \\
\text { Days }\end{array}$ & $\stackrel{5}{\text { Days }}$ & $\stackrel{1}{\text { Week }}$ & $\begin{array}{c}6 \\
\text { Weeks }\end{array}$ \\
\hline $\begin{array}{r}1 \\
2 \\
3 \\
4 \\
5 \\
6 \\
7 \\
8 \\
9 \\
10 \\
11 \\
12 \\
13 \\
14 \\
15 \\
16 \\
17 \\
18 \\
19 \\
20\end{array}$ & $\begin{array}{c}23 \\
69 \\
26 \\
20 \\
55 \\
38 \\
22 \\
36 \\
56 \\
18 \\
33 \\
25 \\
30 \\
68 \\
28 \\
20 \\
31 \\
21 \\
6 \\
16\end{array}$ & $\begin{array}{l}27 \\
84 \\
28 \\
26 \\
72 \\
50 \\
30 \\
38 \\
63 \\
26 \\
38 \\
38 \\
41 \\
61 \\
38 \\
22 \\
41 \\
25 \\
15 \\
16\end{array}$ & $\begin{array}{r}31 \\
125 \\
33 \\
28 \\
128 \\
83 \\
35 \\
50 \\
69 \\
27 \\
41 \\
41 \\
47 \\
66 \\
44 \\
31 \\
44 \\
28 \\
19 \\
19\end{array}$ & $\begin{array}{r}22 \\
135 \\
44 \\
38 \\
75 \\
85 \\
41 \\
53 \\
79 \\
31 \\
46 \\
47 \\
61 \\
75 \\
47 \\
39 \\
56 \\
29 \\
13 \\
22\end{array}$ & $\begin{array}{r}16 \\
68 \\
27 \\
16 \\
44 \\
42 \\
16 \\
25 \\
35 \\
13 \\
19 \\
30 \\
30 \\
56 \\
42 \\
38 \\
32 \\
22 \\
8 \\
13\end{array}$ & $\begin{array}{r}14 \\
48 \\
28 \\
9 \\
32 \\
26 \\
17 \\
19 \\
26 \\
9 \\
13 \\
24 \\
25 \\
26 \\
20 \\
34 \\
12 \\
9 \\
13\end{array}$ & $\begin{array}{r}11 \\
38 \\
24 \\
14 \\
28 \\
19 \\
16 \\
13 \\
22 \\
9 \\
13 \\
16 \\
21 \\
13 \\
15 \\
22 \\
6 \\
8 \\
11\end{array}$ & $\begin{array}{r}13 \\
24 \\
22 \\
8 \\
13 \\
14 \\
13 \\
17 \\
16 \\
13 \\
9 \\
13 \\
16 \\
11 \\
13 \\
16 \\
24 \\
6 \\
8 \\
13\end{array}$ & $\begin{array}{r}12 \\
30 \\
24 \\
11 \\
36 \\
16 \\
13 \\
16 \\
13 \\
13 \\
12 \\
17 \\
15 \\
13 \\
13 \\
25 \\
19 \\
7 \\
11 \\
13\end{array}$ & $\begin{array}{l}14 \\
25 \\
68 \\
72 \\
22 \\
24 \\
38 \\
47 \\
16 \\
38 \\
31 \\
28 \\
32 \\
28 \\
16 \\
15 \\
20\end{array}$ \\
\hline
\end{tabular}

basophil counts for the group varied considerably at any one time interval, the changes in each individual were remarkably consistent and adhered closely to the pattern for the mean.

The total leucocyte and eosinophil counts followed the same general pattern (Table 2), but the peak eosinophil count was not reached until the second day, and the eosinophil counts in any one infant showed wide variation.

\section{Comment}

Previously recorded data on basophil counts in the newborn have been based on differential counts made from blood smears. Elder and Hutchison (1895) found no basophils in the cord blood of 12 infants. Lippman (1924) stated that basophils are relatively numerous at birth, the average count being 153 per c.mm., and that the number decreases rapidly to 50 per c.mm. at 6 hours and to 6 per c.mm. at 5 days. Kato (1935) reported that basophils are comparatively numerous in the newborn period, but did not give any values. Wegelius (1948) found average counts of 50 basophils per c.mm. at birth and 45 per c.mm. at 2 hours. The present results with the more accurate counting-chamber technique confirm that basophils are numerous in the immediate newborn period, but instead of decreasing the number increases during the first 24 hours, with a rapid decrease thereafter. This decrease after the first day was also reported by Forkner (1929), but the very high values of up to 636 cells per c.mm. found by this author were not found in the present series.

In most of the infants the basophil counts followed the general pattern very closely, in contrast to the eosinophil counts, which fluctuated widely. This does not bear out Lippman's statement (1924) that basophilic leucocytes are the most variable of all blood cells; in fact the basophil counts have been found to be remarkably consistent in any one individual.

The mean values for eosinophil counts and the

TABLE 2

\begin{tabular}{|c|c|c|c|c|c|c|c|c|c|c|c|}
\hline Time interval & . & Birth & $\frac{1}{2}$ hour & 4 hours & 24 hours & 2 days & 3 days & 4 days & 5 days & 1 week & 6 weeks \\
\hline \multicolumn{2}{|c|}{ Number of counts } & 20 & 20 & 20 & 20 & 20 & 19 & 19 & 20 & 20 & 17 \\
\hline \multirow{2}{*}{$\begin{array}{l}\text { Basophils } \\
\text { per c.mm. }\end{array}$} & \multirow{2}{*}{$\begin{array}{l}\text { Mean } \\
\text { Range } \\
\text { Standard } \\
\text { deviation }\end{array}$} & $\begin{array}{c}32 \\
6-69\end{array}$ & $\begin{array}{c}39 \\
15-84\end{array}$ & $\begin{array}{c}49 \\
19-128\end{array}$ & $\begin{array}{c}52 \\
13-135\end{array}$ & $\begin{array}{c}30 \\
8-68\end{array}$ & $\begin{array}{c}21 \\
9-48\end{array}$ & $\begin{array}{c}17 \\
6-38\end{array}$ & $\begin{array}{c}14 \\
6-24\end{array}$ & $\begin{array}{c}16 \\
7-36\end{array}$ & $\begin{array}{c}31 \\
14-72\end{array}$ \\
\hline & & $17 \cdot 2$ & $18 \cdot 6$ & $31 \cdot 0$ & $27 \cdot 9$ & $30 \cdot 4$ & $10 \cdot 2$ & $7 \cdot 7$ & $4 \cdot 9$ & $7 \cdot 1$ & $17 \cdot 1$ \\
\hline \multirow{2}{*}{$\begin{array}{l}\text { Eosinophils } \\
\text { per c.mm. }\end{array}$} & \multirow{2}{*}{$\begin{array}{l}\text { Mean } \\
\text { Range } \\
\text { Standard } \\
\text { deviation }\end{array}$} & $\begin{array}{c}179 \\
48-426\end{array}$ & $\begin{array}{c}217 \\
68-404\end{array}$ & $\begin{array}{c}234 \\
78-438\end{array}$ & $\begin{array}{c}330 \\
100-705\end{array}$ & $\begin{array}{c}362 \\
153-689\end{array}$ & $\begin{array}{c}312 \\
113-582\end{array}$ & $\begin{array}{c}241 \\
72-400\end{array}$ & $\frac{226}{60-366}$ & $\begin{array}{c}266 \\
63-460\end{array}$ & $\begin{array}{c}305 \\
122-510\end{array}$ \\
\hline & & 107 & 105 & 116 & 180 & 171 & 142 & 101 & 92 & 104 & 129 \\
\hline \multirow{2}{*}{$\begin{array}{l}\text { Total } \\
\text { leucocytes } \\
\text { in thousands } \\
\text { per c.mm. }\end{array}$} & \multirow{2}{*}{$\begin{array}{l}\text { Mean } \\
\text { Range } \\
\text { Standard } \\
\text { deviation }\end{array}$} & $\frac{11 \cdot 1}{9 \cdot 1-17: 0}$ & $\begin{array}{c}14 \cdot 3 \\
10 \cdot 8-19 \cdot 0\end{array}$ & $\begin{array}{c}18 \cdot 3 \\
12 \cdot 7-26 \cdot 4\end{array}$ & $\begin{array}{c}19 \cdot 5 \\
11 \cdot 2-29 \cdot 6\end{array}$ & $\begin{array}{c}12 \cdot 6 \\
8 \cdot 4-17 \cdot 8\end{array}$ & $\frac{10 \cdot 4}{6 \cdot 8-15 \cdot 4}$ & $\frac{9 \cdot 1}{6 \cdot 3-14 \cdot 4}$ & $\begin{array}{l}9 \cdot 0 \\
6 \cdot 5-12 \cdot 5\end{array}$ & $\frac{9 \cdot 6}{6 \cdot 5-13 \cdot 2}$ & $\begin{array}{c}9 \cdot 6 \\
7 \cdot 7-12 \cdot 1\end{array}$ \\
\hline & & $2 \cdot 0$ & $1 \cdot 9$ & $3 \cdot 7$ & $4 \cdot 5$ & $2 \cdot 7$ & $2 \cdot 3$ & $1 \cdot 8$ & $1 \cdot 7$ & $1 \cdot 6$ & $1 \cdot 2$ \\
\hline
\end{tabular}


changes which occur following birth are very similar to those reported by Lippman (1924). The values are of the same order as those found by Burrell (1953), but the very low counts which she recorded during the first three days and the progressive rise thereafter were not encountered. The total leucocyte counts conform to the general pattern reported by other authors (Lippman, 1924; Forkner, 1929; Kato, 1935; Wegelius, 1948).

In the present state of knowledge concerning the function of the basophil, the significance of the changes which occur in the newborn period is uncertain. There is good evidence that basophils are concerned with the carriage of heparin (Behrens and Taubert, 1952; Martin and Roka, 1953). Furthermore, a relationship between the numbers of basophils and eosinophils and the level of histamine in the blood (Code and Mitchell, 1954) suggests that these two types of cell may share the function of histamine carriage. Little is known about the metabolism of heparin and of histamine in the newborn infant. There is some evidence, however, that the cord blood content of both substances is high (Piccoli, 1950; Pettay, 1950) which would accord with the present observations that both basophils and eosinophils are numerous at birth.

\section{Summary}

Circulating basophils have been counted in 20 infants at frequent intervals after birth. The counts were made on capillary blood using a chamber method, and the values obtained have been compared with those reported previously. Counts of eosinophils and total leucocyte counts were made simultaneously.

Basophils are relatively numerous at birth and increase in number during the first 24 hours, decreasing thereafter to reach a minimum level on the fifth day after birth. The number then increases again and at 6 weeks is approximately double that recorded at 1 week.

I am grateful to Professor J. L. Henderson for his advice and criticism.

\section{References}

Behrens, M. and Taubert, M. (1952). Klin. Wschr., 30, 76 Burrell, J. M. (1953). Archives of Disease in Childhood, 23, 140

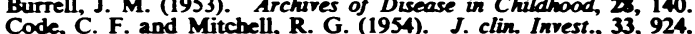
Code, C. F. and Mitchell, R. G. (1954), J. clin. Invest., 33, 924 Findlay, L. (1946). Archives of Disease in Childhood, 21, 195.

Forkner, C. E. (1929). Bull. Johns Hopk. Hosp., 45, 75.

Graham, H. T., Wheelwright, F., Parish, H. H., Marks, A. R. and Lowry, O. H. (1952). Fed. Proc., 11, 350.

James G W III (1953). Personal communication.

James, G. W., Iil. (1935). J. Pediat., 7, 7.

Lippman, H. S. (1924). Amer. J. Dis. Child., 27, 473.

Lucas, W. P., Dearing. B. F., Hoobler, H. R., Cox, A., Jones, M. R and Smyth, F. S. (1921). Ibid., 22, 525.

Martin, H. and Roka, L. (1953). Acta haemat., Basel, 10, 26.

Moore, J. E., III. and James, G. W., III. (1953). Proc. Soc. exp. Bid. N.Y., 82, 601 .

Pettay, O. (1950). Acta paediat., Uppsala, 39, 283.

Piccoli, R. (1950). Boll. Soc. ital. Biol. sper., $26,623$.

Riky, J. F. and West, G. B. (1953). J. Physiol., Lond., 120, 528

Wegelius, R. (1948). Acta paediat., Uppsala, 35, Suppl. 4. 